\title{
Role of Crop Rotations in the Dynamic of Soil Organic Matter Pools
}

\author{
Rodrigo Santos Moreira ${ }^{1}$, Marcio Koiti Chiba ${ }^{1}$, Isabella Clerici De Maria ${ }^{1}$, Caio César Zito Siqueira ${ }^{1}$, \\ Aildson Pereira Duarte ${ }^{1} \&$ Debora Marcondes Bastos Pereira Milori ${ }^{2}$ \\ ${ }^{1}$ Agronomic Institute of Campinas, Brazil \\ ${ }^{2}$ Brazilian Agricultural Research Corporation (EMBRAPA), Brazil \\ Correspondence: Rodrigo Santos Moreira, Agronomic Institute of Campinas, Brazil. E-mail: \\ rodrigosagro@yahoo.com.br
}

Received: April 23, 2018

Accepted: May 27, $2018 \quad$ Online Published: July 15, 2018

doi:10.5539/jas.v10n8p341

URL: https://doi.org/10.5539/jas.v10n8p341

\begin{abstract}
Soil organic matter is considered a key attribute for a sustainable agricultural production and is influenced by the quantity and quality of the crop residue deposited on the soil surface. Therefore, different crop rotations could change the soil organic matter pools. The objectives of this study were to evaluate the soil carbon pools obtained by chemical and physical fractionation methods and the humification index under different crop rotations in a no-till system. We test the following hypothesis: a) the distribution of $\mathrm{C}$ and $\mathrm{N}$ among the soil organic matter fractions depends on plant species rotation schemes and; $b$ ) labile fractions are more sensitive to the input of crop residues and therefore, more suitable for evaluating the impact of different crop rotations in the soil organic matter quality. We evaluated four crop sequences (corn/corn/corn; corn/wheat/corn; soybean/wheat/corn and soybean/corn/corn) in a no-till system. A five-year reforested area was used as reference. We determined the total $\mathrm{C}$ and $\mathrm{N}$ contents, the mineral-associated $\mathrm{C}$ and $\mathrm{N}$, the light fraction of $\mathrm{C}$ and $\mathrm{N}$, the labile carbon extracted with $\mathrm{KMnO}_{4}$ and the soil organic matter humification index. We found narrow differences between the crop rotation systems in the total $\mathrm{C}$ and $\mathrm{N}$ levels, the mineral-associated $\mathrm{C}$ and $\mathrm{N}$ fractions and the labile $\mathrm{C}$ extracted with $\mathrm{KMnO}_{4}$. The diversification of the agricultural system with soybean in crop rotation favored the accumulation of light fraction $\mathrm{C}$ and $\mathrm{N}$ in the soil that were more efficient to provide information about the changes in the soil organic matter quality.
\end{abstract}

Keywords: quality indicators, soil quality, carbon fractionation, nitrogen cycling, crop yield

\section{Introduction}

Soil organic matter (SOM) is a complex mix of plant and animal residues in various stages of decomposition and synthesis that plays an essential role in the chemical, physical and biological processes relate to soil ecosystem functions. For this reason, maintaining the SOM status is particularly important to preserve the capacity of soils sustain plant production (Favoretto et al., 2008).

Due to its heterogeneous nature, a separation of SOM into pools that differ in stability may be useful to understanding the environment functionality of the soil organic carbon (SOC) (Strosser, 2010). Changes in the crop management system altered the quantity and quality of organic residue input in an agricultural soil (Mujuru et al., 2013). Therefore, different crop rotations associated with a no-tillage system may affect the size, cycling and distribution of carbon and nitrogen among the SOM fractions.

Soil is one of the main carbon compartments of the planet. Thus, changes in the total SOC contents due to the agricultural management occur slowly due to the high background C in soil (Blair et al., 1995). However, labile fractions tend to respond faster to the crop management changes and by driving crucial soil processes, such as nutrient cycling and biological activity, these fractions can significantly influence the quality of an agricultural land (Chen et al., 2012; Duval et al., 2013).

Labile carbon is the fraction of SOM that is easily decomposed and could be estimate by the chemical oxidation with $\mathrm{KMnO}_{4}$ (Blair et al., 1995) and by physical fractionation methods (Cambardella \& Elliott, 1992). The light fraction is a labile pool of $\mathrm{C}$, which consists of organic materials in various stages of decay, but no having undergone a complete transformation and still retains characteristics of the source material (Ramnarine et al., 2014). In comparison, the mineral-associated fraction is composed of a highly decomposed organic material that is chemically stabilized, therefore, is more resistant to changes (Junior et al., 2014). 
Another way to characterize SOM is through the humification index (Milori et al., 2006) that can provide information about the stability and its availability of $\mathrm{C}$ to the soil microorganisms. High rates of straw deposition on the soil surface in no-tillage can increase the labile forms of carbon and decrease the humification index of the organic matter in the superficial layers (Segnini et al., 2013; Martins et al., 2011). Although no-tillage is a conservationist agricultural system widely adopted, many farmers do not use an adequate crop rotation, which may compromise the ability of this system in improving and conserve the soil quality.

Hence, the objectives of this study were to evaluate the soil carbon pools isolated by chemical and physical methods and the humification index of SOM in different crop rotations. We test the following hypothesis: a) the distribution of $\mathrm{C}$ and $\mathrm{N}$ among the SOM fractions depends on plant species rotation schemes and; b) labile fractions are more sensitive to the input of crop residues and therefore more suitable for evaluating the impact of different crop rotations in the soil organic matter quality. We hope that the distribution of carbon and nitrogen among the SOM pools can provide information about how different management systems influence the quality of agricultural soils.

\section{Materials and Methods}

\subsection{Study Site}

The field trial was established at the research station of the Sao Paulo Agency of Agribusiness Technology, city of Capao Bonito, Sao Paulo State, Brazil (aprox. coordinates $24^{\circ} 00^{\prime} 14^{\prime \prime} \mathrm{S}$ and $48^{\circ} 20^{\prime} 21^{\prime \prime} \mathrm{W}$ ) from September 2010 to September 2015. The soil was classified as a clayey Ferralsol (FAO, 1988). The mean annual temperature is $18.6^{\circ} \mathrm{C}$ and the mean annual rainfall is $1241 \mathrm{~mm}$.

The experiment consisted of four crop sequences (1: corn/corn/corn, CCC; 2: corn/wheat/corn, CWC; 3: soybean/wheat/corn, SWC; and 4: soybean/corn/corn, SCC) in a randomized complete block design. Each treatment was replicated 4 times and applied to $20 \times 10 \mathrm{~m}$ plots $\left(200 \mathrm{~m}^{2}\right)$. As reference, soil from a five-year reforested site located $15 \mathrm{~m}$ to the experiment was used. Crop rotation arrangements are present in Table 1.

Table 1. Crop rotation arrangements used in the experiment

\begin{tabular}{|c|c|c|c|c|c|c|c|c|c|c|}
\hline \multirow{2}{*}{$\begin{array}{l}\text { Safra } \\
\text { Treatments }\end{array}$} & \multicolumn{2}{|c|}{$2010 / 2011$} & \multicolumn{2}{|c|}{$2011 / 2012$} & \multicolumn{2}{|c|}{$2012 / 2013$} & \multicolumn{2}{|c|}{$2013 / 2014$} & \multicolumn{2}{|c|}{$2014 / 2015$} \\
\hline & Summer & Winter & Summer & Winter & Summer & Winter & Summer & Winter & Summer & Winter \\
\hline $\mathrm{CCC}$ & corn & corn & corn & corn & corn & corn & corn & corn & corn & corn \\
\hline $\mathrm{CWC}$ & corn & wheat & corn & wheat & corn & wheat & corn & wheat & corn & wheat \\
\hline SWC & soybean & wheat & corn & wheat & soybean & wheat & corn & wheat & soybean & wheat \\
\hline $\mathrm{SCC}$ & soybean & corn & corn & corn & soybean & corn & corn & corn & soybean & corn \\
\hline
\end{tabular}

Note. $\mathrm{CCC}=$ corn/corn/corn; $\mathrm{CWC}=$ corn/wheat/corn; $\mathrm{SWC}=$ soybean/wheat/corn; $\mathrm{SCC}=$ soybean/corn/corn.

\subsection{Processing of Yield Data}

Grain yield of corn (Zea mays L.), soybean (Glycine max L.) and wheat (Triticum aestivum L.) were collected at each plot for 5 years (10 harvests). Productivity of every plot was expressed by standardization of yield data as follows:

$$
\mathrm{RCY}=\left[\sum\left(\mathrm{Yp} / \mathrm{Y}_{\max }\right)\right] / 10
$$

Where, $\mathrm{RCY}$ is the relative cumulative yield of plot $p$ (a value between 0 and 1$), \mathrm{Y}_{\mathrm{p}}$ is the yield of parcel $p\left(\mathrm{t} \mathrm{ha}^{-1}\right)$ and $\mathrm{Y}_{\max }$ is the maximum yield, considering the crop of the plot $p$, on the total research site over all plots $\left(\mathrm{t} \mathrm{ha}^{-1}\right)$.

\subsection{Soil Sampling and Analyses}

Soil sampling was performance in October 2006 after harvest at 0-10, 10-20, 20-30 and 30-40 cm soil layers. Soil samples were air-drying, and visible crop residues were removed by handpicking before passing the soil through a 2-mm sieve to obtain the fine-earth fraction used for soil analyses.

The total soil organic carbon (TOC) and total nitrogen (TN) was determined by dry combustion, using an elemental analyzer LECO-CN. Labile carbon $\left(\mathrm{C}_{\mathrm{KMnO}_{4}}\right)$ was determined by chemical oxidation with $\mathrm{KMnO}_{4}$ according to Blair et al. (1995). For physical fractionation, $10 \mathrm{~g}$ of soil sample and $30 \mathrm{~mL}$ of $\mathrm{Na}$ hexametaphosphate solution $\left(5 \mathrm{~g} \mathrm{~L}^{-1}\right)$ were added to a $50 \mathrm{ml}$ centrifuge tubes and horizontally shaken for $15 \mathrm{~h}$ (200 rpm). The soil suspension was passed through a $0.053 \mathrm{~mm}$ mesh was rinsed with a weak stream of distilled water, dried at $50^{\circ} \mathrm{C}$, ground and analyzed for mineral-associated fraction carbon (MFC) and mineral-associated 
fraction nitrogen (MFN). The particles retained at $0.053 \mathrm{~mm}$ mesh were transferred to centrifuge tube and received $20 \mathrm{~mL} \mathrm{NaI}$ solution (density of $1.8 \mathrm{Mg} \mathrm{m}^{-3}$ ). The suspensions were shaken for 2 min and centrifuged at $3500 \mathrm{rpm}$ for 15 minutes. The supernatant containing the light fraction was vacuum filtered through a $0.45 \mathrm{~mm}$ fiberglass filter. The retained, denominated as light fraction were rinsed with distilled water to remove Nal salt, dried at $50{ }^{\circ} \mathrm{C}$, grounded in an agate mortar and analyzed for total $\mathrm{C}$ and $\mathrm{N}$ using elemental analyzer LECO-CN (Cambardella \& Elliott, 1992).

\subsection{Humification Index}

Laser-Induced Fluorescence Spectroscopy (LIFS) was used to assess the degree of humification of SOM (Milori et al., 2002). Pellets of approximately $2 \mathrm{~mm}$ thick and $10 \mathrm{~mm}$ in diameter were prepared with a hydraulic press using approximately $0.5 \mathrm{~g}$ of soil and applying 1,300 MPa for $5 \mathrm{~min}$. These soil pellets were inserted into a bench custom-made apparatus in order to acquire the LIFS data. The two faces of the pellet were measured in four replicates. Samples were irradiated with $458 \mathrm{~nm}$ blue radiation, emitted by argon laser equipment (Coherent Innova 90-6, Coherent Inc., Santa Clara, CA) with power of around $300 \mathrm{~mW}$ (Milori et al., 2006). The ratio of the area under this fluorescence emission divided by the total $\mathrm{C}$ content (in $\mathrm{g} \mathrm{kg}^{-1}$ ) was defined as the SOM humification index $\left(\mathrm{H}_{\mathrm{LIF}}\right)$ and is expressed as arbitrary units (a.u.) (Milori et al., 2006).

\subsection{Data Analyses}

Data were analysed by the analysis of variance (ANOVA-F-test) using SISVAR 5.0 software (Build, Lavras, Brazil). To compare the means among the treatments a Least Significant Differences was used by the $t$ test. All assumptions required by the ANOVA were verified and confirmed before calculations. To evaluate the correlations between the carbon and nitrogen pools, the Pearson correlation was applied. All tests were performed using $p<0.05$.

\section{Results and Discussion}

After five years under no-till, the soil from the four different management systems had lower levels of $\mathrm{C}$ and $\mathrm{N}$ fractions compared to the reference area (Figure 1). However, at the 10-20 cm depth we do not found a significant difference to TOC and TN between the rotation SWC and the reference area, while in the layer of $30-40 \mathrm{~cm}$ there is no significant difference among all treatments (Figure 1).
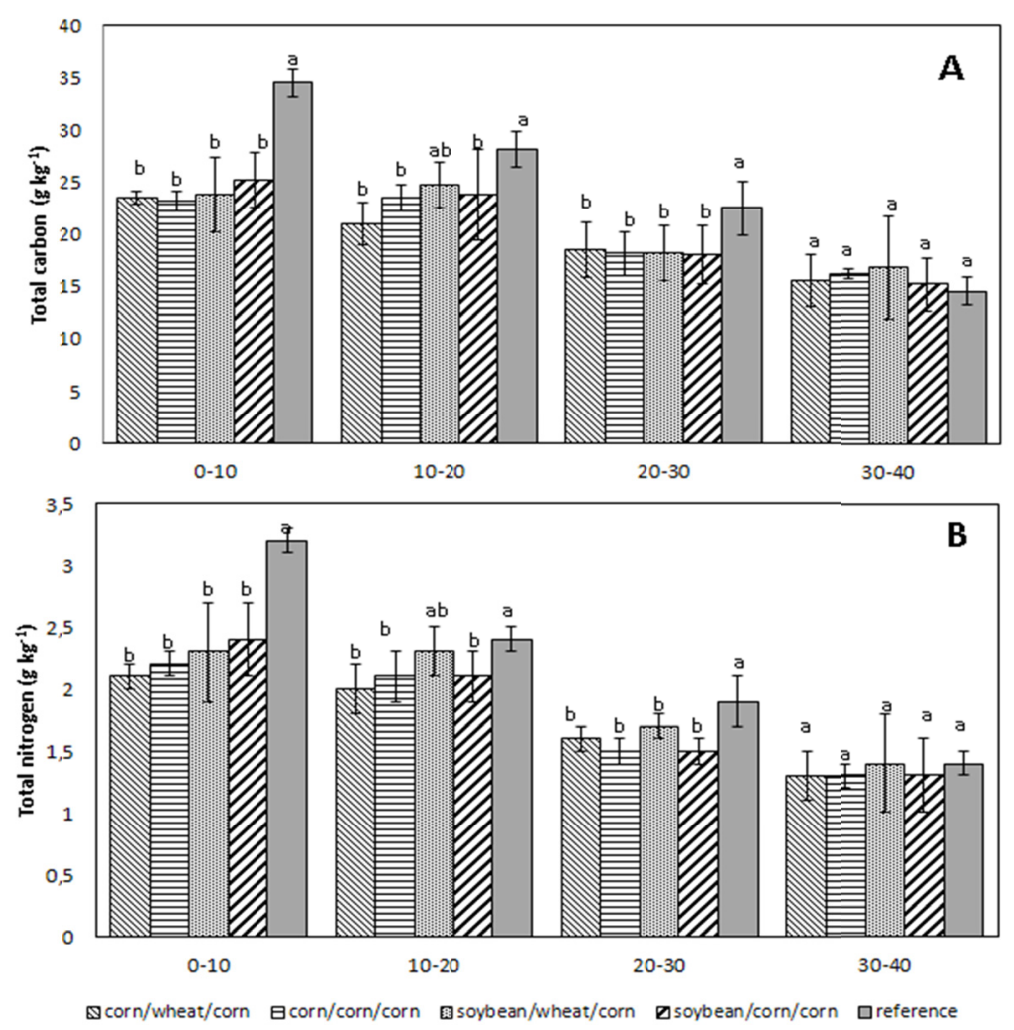

Figure 1. Total carbon (A) and nitrogen (B) contents in different treatments at four soil depths. Different latters indicate significant difference among treatments at $\mathrm{p}<0.05$ 
Cultivation changed the amount and the quality of crop residues input to the soil and allowed a faster oxidation of the SOM compared to the natural vegetation sites (Mujuru et al., 2013; Junior et al., 2014). Depending on the agricultural management system carried out, the decrease of SOM can, therefore, reduce soil fertility, negatively impact soil structure, lowers water holding capacity and consequently lead to a decrease in crop yield (Islam et al., 2015; Lal, 2015; Vanhie et al., 2015). As observed by the high correlation $\left(\mathrm{R}^{2}=0.95\right)($ Table 2$)$ between total $\mathrm{C}$ and $\mathrm{N}$ contents, the both follows a similar pattern. Thus, the maintenance of SOM levels could increase the $\mathrm{N}$ supply in soil, which could enhance the crop productivity.

Table 2. Linear correlations among the TOC, TN and soil $\mathrm{C}$ and $\mathrm{N}$ fractions

\begin{tabular}{llllllll}
\hline Factor & TOC & TN & MFC & MFN & LFC & LFN & C $_{\mathrm{KMnO} 4}$ \\
\hline TOC & 1 & & & & & & \\
TN & $0.95^{* *}$ & 1 & & & & & \\
MFC & $0.90^{* *}$ & $0.94^{* *}$ & 1 & & & & \\
MFN & $0.83^{* *}$ & $0.91^{* *}$ & $0.93^{* *}$ & 1 & & & \\
LFC & $0.64^{* *}$ & $0.66^{* *}$ & $0.62^{* *}$ & $0.61^{* *}$ & 1 & & \\
LFN & $0.72^{* *}$ & $0.74^{* *}$ & $0.67^{* *}$ & $0.62^{* *}$ & $0.81^{* *}$ & 1 & \\
C & $0.70^{* *}$ & $0.72^{* *}$ & $0.66^{* *}$ & $0.65^{* *}$ & $0.40^{* *}$ & $0.49^{* *}$ & 1
\end{tabular}

Note. ${ }^{* *}$ Significant at $p<0.01 . \mathrm{TOC}=$ total organic carbon; $\mathrm{TN}=$ total nitrogen; $\mathrm{MFC}=$ mineral-associated fraction carbon; $\mathrm{MFN}=$ mineral-associated fraction nitrogen; $\mathrm{LFC}=$ light fraction carbon; $\mathrm{LFN}=$ light fraction nitrogen; $\mathrm{C}_{\mathrm{KMnO}}=$ carbon extracted with $\mathrm{KMnO}_{4}$.

Due to the importance of the organic matter, soil organic carbon is considered a key attribute to evaluate how management practices affect soil quality (Favoretto et al., 2008). However, total $\mathrm{C}$ and $\mathrm{N}$ contents changed slightly between the crop rotations. These results indicate that five years were not sufficient for the crop rotation systems to promote a significant increase in TOC content when compared with monoculture and grasses succession systems (CCC and CWC treatments). Therefore, the evaluation of different compartments of the SOM can provide an insight into how the management systems adopted affect the dynamics of soil carbon.

Regarding the carbon and nitrogen fractions analyzed in this study, we observed that the amounts of MFC and MFN in the soil surface $(0-10 \mathrm{~cm})$ were higher in the reference site compared to the cultivated area (Figure 2). For MFN in the 30-40 cm depth, the rotation CWC resulted in higher values than the reference area (Figure 3). Reference site also had a higher labile carbon $\left(\mathrm{C}_{\mathrm{KMnO} 4}\right)$ content compared to the all rotations, except for the 30-40 $\mathrm{cm}$ soil layer (Figure 3). In relation to the light fraction of SOM, in general, the rotation SCC and the reference site showed the highest levels of LFC and LFN in all depths while in the rotation CWC the contents of C and N in this fraction were significantly lower (Figure 3). As shown in Table 2, all the $\mathrm{C}$ and $\mathrm{N}$ pools were positively correlated at $p<0.05$. 

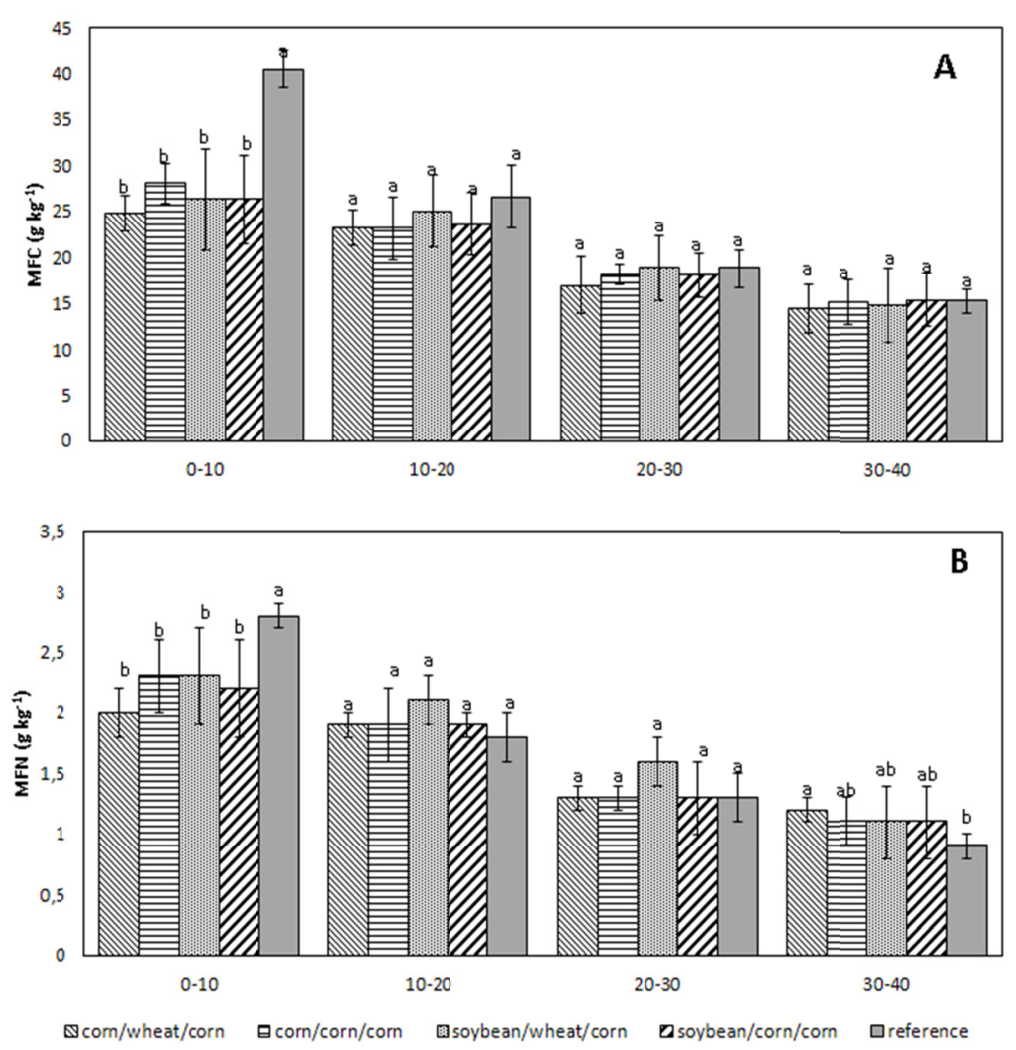

Figure 2. Mineral-associated fraction carbon (A) and nitrogen (B) contents in different treatments at four soil depths. Different latters indicate significant difference among treatments at $\mathrm{p}<0.05$ 

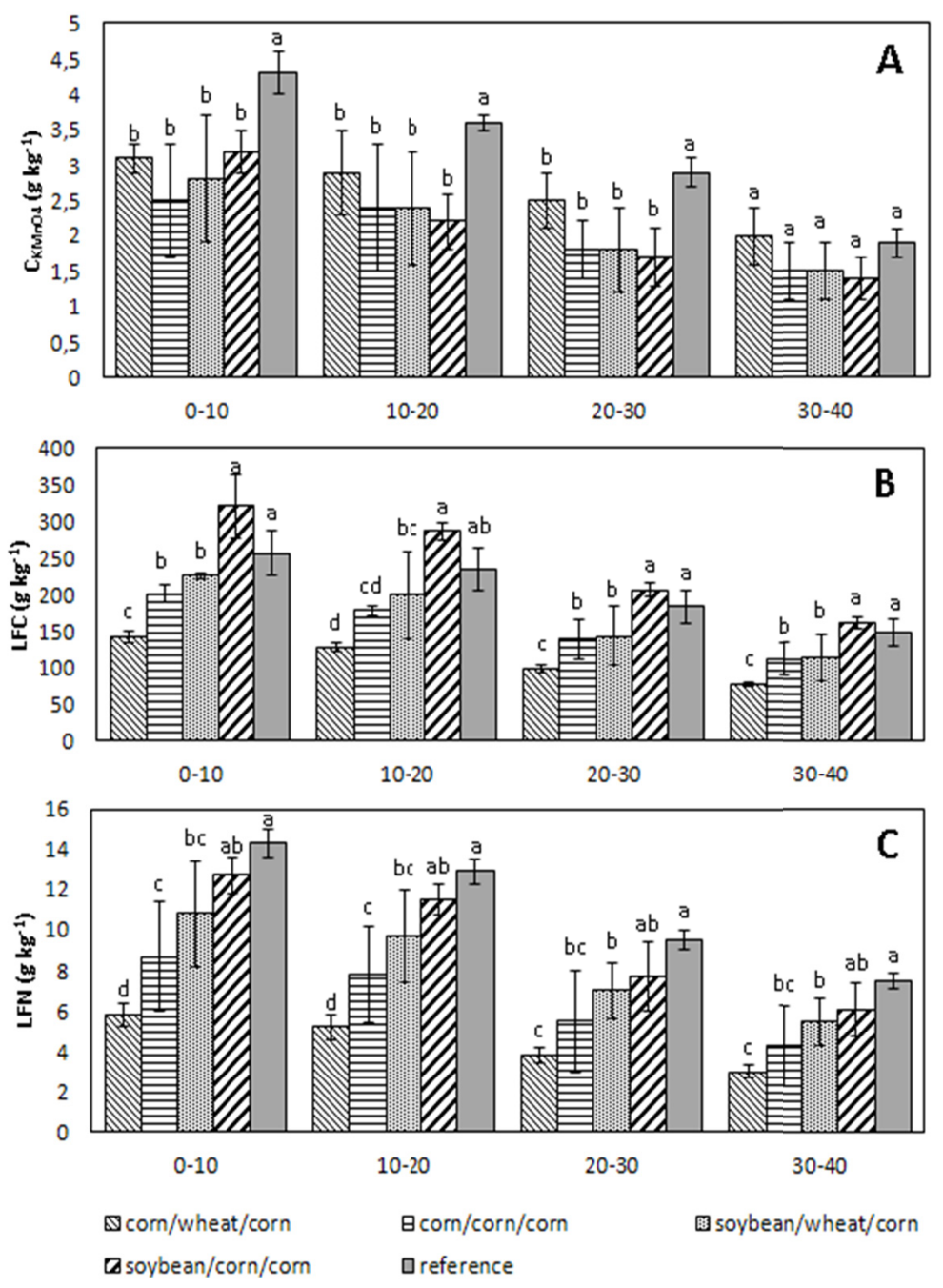

Figure 3. Carbon extracted with $\mathrm{KMnO}_{4}(\mathrm{~A})$, light fraction C (B) and $\mathrm{N}(\mathrm{C})$ contents in different treatments at four soil depths. Different latters indicate significant difference among treatments at $\mathrm{p}<0.05$

The percentage of $\mathrm{C}_{\mathrm{KMnO}}$ and LFC in TOC were approximately $40 \%$ smaller than the mineral-associate carbon pool in all management systems (Table 3). These results agree with other authors (Bayer et al., 2006; Junior et al., 2014; Ryals et al., 2014) and can be an indicative that the highest proportion of carbon in mineral-associated fractions than in labile fractions was probably due to physical and chemical stability of mineral-associated carbon. The interaction between the soil organic and mineral matrix can promote a greater protection of the carbon against microbial decomposition (Jamala \& Oke, 2013). Thus, due to the recalcitrance of mineral-associated soil organic matter, the environmental conditions are favorable to decomposition of mainly carbon labile fractions.

Carbon and nitrogen in the light fraction were more sensitive to changes in management systems than $\mathrm{C}_{\mathrm{KMnO}}$ (Figure 3). Several studies report that LFC has a great potential to discriminate different agricultural management systems (Tan et al., 2007; Dou et al., 2008; Soon et al., 2007; Ramnarine et al., 2014). The physical fractionation can isolate the fraction that still shows some structural characteristics of its precursor, which is partially decomposed (Ramnarine et al., 2014). The light fraction showed a $\mathrm{C} / \mathrm{N}$ ratio average of 24.6, approaching to what is verified in fresh material. This fraction is the most easily accessible for microorganisms with a short residence time in the soil, ranging from 1 to 5 years (Janzen et al., 1992). For this reason, this fraction of organic matter constitutes a transient reserve of $C$ in the soil (Souza et al., 2016) and serves as energy source for microorganisms, as well as a labile nutrient reservoir (Wagai et al. 2009). 
Although $\mathrm{C}_{\mathrm{KMnO}}$ is considered a labile fraction of SOM, Vieira et al. (2007) showed that the chemical oxidation might attack even some mineral-associated organic material, which is not readily available for soil microorganism. The results presented in this paper supported this assumption once the proportion of the $\mathrm{C}_{\mathrm{KMnO}}$ in TOC ranged between 9.5 and $14.1 \%$, while the LFC in TOC ranged between 4.6 to $10.2 \%$ (Table 3 ). Thus, the chemical oxidation with $\mathrm{KMnO}_{4}$ may overestimates the levels of the soil labile $\mathrm{C}$ and shows why $\mathrm{C}_{\mathrm{KMnO} 4}$ not present the same sensitivity that the LFC to changes in the crop rotation system.

Despite the no significant difference in total $\mathrm{C}$ and $\mathrm{N}$ contents between crop rotations, changes in labile carbon forms could be detected early compared to the TOC (Gong et al., 2009; Chen et al., 2009; Zhu et al., 2015). In this study, all the $\mathrm{C}$ and $\mathrm{N}$ pools analyzed were positively correlated each other (Table 2). These results indicate that more labile compartments of $\mathrm{C}$ and $\mathrm{N}$ can be used to provide early information about how different management practices may affect the SOM. Thus, it is possible that treatments with higher LFC levels could, in the future, lead to an increase in total SOM. However, to substantiate this assertion, a long-term study is required.

Table 3. Proportion of carbon and nitrogen fractions to total organic carbon and total nitrogen of different crop systems at four soil depths

\begin{tabular}{lllllll}
\hline Soil depth (cm) & CWC & CCC & SWC & SCC & Reference & CV\% \\
\hline$M F C / T O C(\%)$ & & & & & & \\
$0-10$ & $47.0 \pm 4.2 \mathrm{a}$ & $51.0 \pm 1.7 \mathrm{a}$ & $49.7 \pm 5.6 \mathrm{a}$ & $46.2 \pm 6.7 \mathrm{a}$ & $50.3 \pm 2.8 \mathrm{a}$ & 8.8 \\
$10-20$ & $49.3 \pm 5.6 \mathrm{a}$ & $45.8 \pm 10.0 \mathrm{a}$ & $45.8 \pm 9.0 \mathrm{a}$ & $44.2 \pm 2.2 \mathrm{a}$ & $40.7 \pm 7.4 \mathrm{a}$ & 15.7 \\
$20-30$ & $40.5 \pm 2.9 \mathrm{ab}$ & $46.1 \pm 5.0 \mathrm{a}$ & $46.4 \pm 5.1 \mathrm{a}$ & $44.7 \pm 2.2 \mathrm{a}$ & $36.2 \pm 7.4 \mathrm{~b}$ & 12.7 \\
$30-40$ & $41.5 \pm 4.6 \mathrm{a}$ & $43.0 \pm 9.0 \mathrm{a}$ & $44.1 \pm 3.7 \mathrm{a}$ & $44.5 \pm 4.7 \mathrm{a}$ & $45.5 \pm 4.0 \mathrm{a}$ & 12.6 \\
\hline$L F C / T O C(\%)$ & & & & & \\
$0-10$ & $6.7 \pm 3.0 \mathrm{a}$ & $7.2 \pm 2.9 \mathrm{a}$ & $8.6 \pm 1.4 \mathrm{a}$ & $10.2 \pm 3.8 \mathrm{a}$ & $9.6 \pm 1.0 \mathrm{a}$ & 31.0 \\
$10-20$ & $5.4 \pm 2.0 \mathrm{c}$ & $5.9 \pm 3.2 \mathrm{bc}$ & $7.3 \pm 1.2 \mathrm{abc}$ & $9.0 \pm 1.3 \mathrm{a}$ & $8.4 \pm 1.1 \mathrm{ab}$ & 24.8 \\
$20-30$ & $4.6 \pm 1.2 \mathrm{c}$ & $5.6 \pm 1.2 \mathrm{abc}$ & $5.4 \pm 0.6 \mathrm{bc}$ & $6.9 \pm 1.4 \mathrm{a}$ & $6.1 \pm 0.9 \mathrm{ab}$ & 16.6 \\
$30-40$ & $4.9 \pm 0.1 \mathrm{~b}$ & $6.8 \pm 1.6 \mathrm{a}$ & $6.0 \pm 0.2 \mathrm{ab}$ & $7.4 \pm 0.9 \mathrm{a}$ & $6.3 \pm 1.2 \mathrm{ab}$ & 16.5 \\
\hline$C_{K M n O 4}-1 \% C(\%)$ & $13.0 \pm 1.0 \mathrm{a}$ & $10.8 \pm 3.5 \mathrm{a}$ & $11.7 \pm 11.7 \mathrm{a}$ & $12.7 \pm 1.9 \mathrm{a}$ & $12.4 \pm 0.9 \mathrm{a}$ & 21.7 \\
$0-10$ & $14.1 \pm 3.3 \mathrm{a}$ & $10.3 \pm 3.3 \mathrm{a}$ & $10.2 \pm 10.2 \mathrm{a}$ & $9.6 \pm 2.4 \mathrm{a}$ & $13.0 \pm 1.1 \mathrm{a}$ & 28.2 \\
$10-20$ & $13.5 \pm 2.9 \mathrm{a}$ & $9.9 \pm 2.7 \mathrm{a}$ & $10.2 \pm 10.2 \mathrm{a}$ & $9.5 \pm 2.4 \mathrm{a}$ & $13.0 \pm 1.2 \mathrm{a}$ & 25.1 \\
$20-30$ & $13.4 \pm 3.0 \mathrm{a}$ & $9.5 \pm 2.4 \mathrm{a}$ & $9.9 \pm 9.9 \mathrm{a}$ & $9.5 \pm 2.4 \mathrm{a}$ & $13.1 \pm 1.0 \mathrm{a}$ & 26.7 \\
$30-40$ & & & & & & \\
$-M F N / T N(\%)$ & $42.3 \pm 3.1 \mathrm{bc}$ & $48.9 \pm 9.6 \mathrm{a}$ & $46.3 \pm 1.7 \mathrm{ab}$ & $42.1 \pm 4.0 \mathrm{bc}$ & $36.9 \pm 1.0 \mathrm{c}$ & 9.2 \\
$0-10$ & $41.0 \pm 2.3 \mathrm{a}$ & $41.7 \pm 5.3 \mathrm{a}$ & $42.5 \pm 1.8 \mathrm{a}$ & $39.2 \pm 2.4 \mathrm{a}$ & $34.4 \pm 2.4 \mathrm{~b}$ & 7.2 \\
$10-20$ & $37.9 \pm 3.3 \mathrm{ab}$ & $42.0 \pm 3.2 \mathrm{~b}$ & $42.7 \pm 5.3 \mathrm{~b}$ & $40.3 \pm 5.5 \mathrm{~b}$ & $31.3 \pm 6.9 \mathrm{c}$ & 13.6 \\
$20-30$ & $39.7 \pm 1.8 \mathrm{a}$ & $36.5 \pm 6.9 \mathrm{ab}$ & $39.8 \pm 2.4 \mathrm{a}$ & $38.1 \pm 3.6 \mathrm{ab}$ & $33.7 \pm 3.4 \mathrm{~b}$ & 10.1 \\
$30-40$ & $3.0 \pm 1.4 \mathrm{a}$ & $4.0 \pm 3.4 \mathrm{a}$ & $4.2 \pm 1.2 \mathrm{a}$ & $4.4 \pm 2.0 \mathrm{a}$ & $5.7 \pm 0.8 \mathrm{a}$ & 47.3 \\
\hline$L F N / T N(\%)$ & $2.5 \pm 0.9 \mathrm{c}$ & $2.8 \pm 1.4 \mathrm{bc}$ & $3.5 \pm 0.7 \mathrm{bc}$ & $4.3 \pm 0.9 \mathrm{~b}$ & $6.7 \pm 1.2 \mathrm{a}$ & 26.9 \\
$0-10$ & $2.7 \pm 0.6 \mathrm{~b}$ & $3.6 \pm 2.1 \mathrm{ab}$ & $3.6 \pm 0.7 \mathrm{ab}$ & $4.6 \pm 1.8 \mathrm{ab}$ & $5.8 \pm 1.0 \mathrm{a}$ & 34.4 \\
$10-20$ & $2.3 \pm 0.2 \mathrm{a}$ & $3.4 \pm 1.9 \mathrm{a}$ & $3.2 \pm 0.6 \mathrm{a}$ & $3.4 \pm 1.2 \mathrm{a}$ & $3.4 \pm 1.0 \mathrm{a}$ & 39.3 \\
$20-30$ & & &
\end{tabular}

Note. Different latters in the lines indicate significant difference among treatments at $p<0.05$. MFC/TOC $=$ proportion of mineral-associated fraction carbon in TOC; LFC = proportion of light fraction carbon in TOC; $\mathrm{EOC}=$ proportion of easy organic carbon in TOC; MFN = proportion of mineral-associated fraction nitrogen in $\mathrm{TN}$; LFN = proportion of light fraction nitrogen in TN.

The relative cumulative yield considering the five years of the study was higher in the treatments with legume-based annual rotation followed by the rotations CCC and CWC (Figure 4). Soil quality influence significantly the crop yield, therefore we expected that well-managed soils could support a sustainable production (Karami et al., 2012; Malhi \& Lemke, 2007). Considering the five years of this study, the treatments with legume-based annual rotation showed a higher relative cumulative yield (Figure 4). Gan et al. (2015) and Islam et al. (2015) observed that the addition of legumes in crop rotation increased the productivity of the agricultural system. According to Fornara and Tilman (2008) the productivity of plants can be favored by the complementarity between grasses and legumes, since grass crops have a high efficiency in the use of nitrogen 
provided by legumes, increasing the biomass production. These results are corroborated by the increase of LFN in SWC and SCC treatments.

The higher relative cumulative yield in SWC and SCC treatments provided a high and diverse input of biomass leading to a buildup of carbon and nitrogen light fraction in the soil. Several studies report enhancements of soil carbon and nitrogen (based on labile fraction characterization) with crop rotation in a no-tillage system (Aziz et al., 2011; Souza et al., 2016; Ramnarine et al., 2014). These results demonstrate that the light fraction can be relate directly to the quality of biomass input on the soil surface in a no-tillage system.

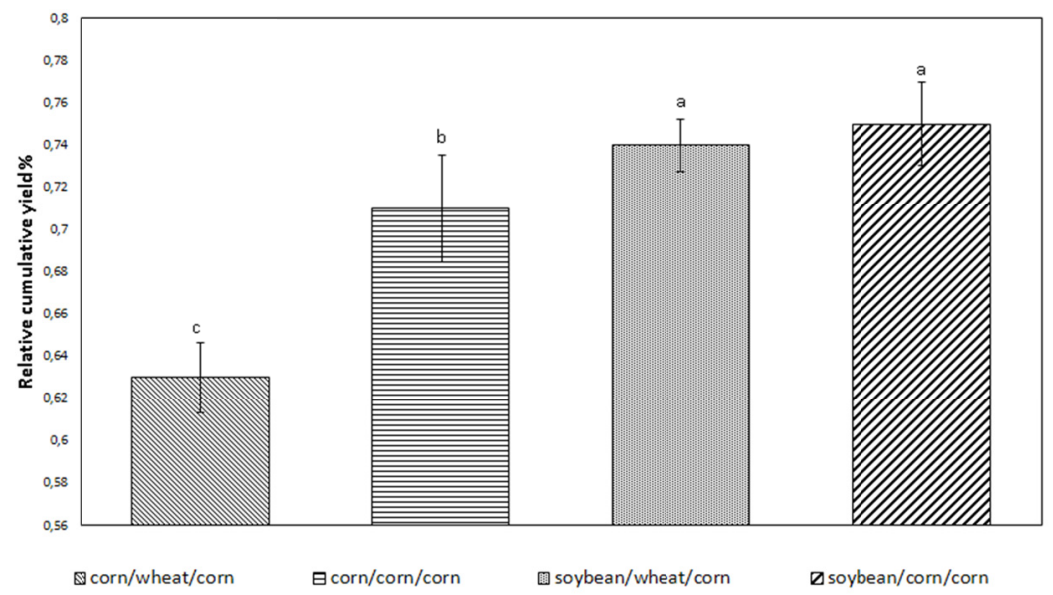

Figure 4. Effects of different crop rotations on the relative cumulative yield. Different latters indicate significant difference among treatments at $p<0.05$

These findings are corroborated by the humification index that was higher in the rotation CWC that presented the lowest relative cumulative yield and, therefore, a lower residue inputs to the soil (Figure 5). Although several studies have shown that no-tillage system tends to reduce the SOM humification index in the soil surface layers (Segnini et al., 2013; Martins et al., 2011; Favoretto et al., 2008), there is little information about how different crop rotation systems affect $\mathrm{H}_{\mathrm{FIL}}$ values. We demonstrated that the association of grasses and legumes in a crop rotation system might increase the biomass production leading to a greater crop residues input on the soil surface, which increases the labile forms of carbon. On the other hand, in the crop systems with low residue input, only more recalcitrant forms of the SOM tend to remain.

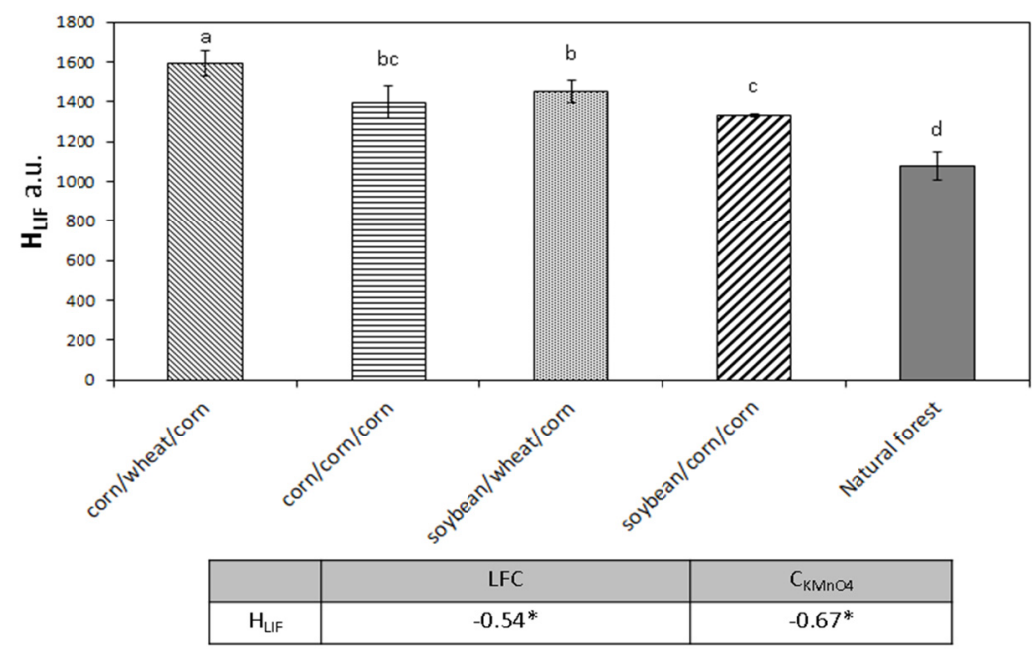

Figure 5. Soil organic matter humification index $\left(\mathrm{H}_{\mathrm{LIF}}\right)$ obtained by Laser-Induced Fluorescence Spectroscopy in the different treatments (A) and linear correlations among the $\mathrm{H}_{\mathrm{LIF}}$, $\mathrm{LFC}$ and $\mathrm{C}_{\mathrm{KMnO}}$. Different latters indicate significant difference among treatments at $\mathrm{p}<0.05$. * Significant at $p<0.05$ 
The reference area presented the lowest humification index of SOM (Figure 5). This result can be explained by the thick layer of litter present in these areas providing a volume of organic material that overwhelms the capacity of microorganisms to metabolize them, reducing the humification index (González-Pérez, 2007). The $\mathrm{H}_{\mathrm{LIF}}$ was negatively correlated with LFC and $\mathrm{C}_{\mathrm{KMnO}}$, showing that there is similarity between the techniques in estimating the lability of the soil organic matter. However, the LFC showed to be more sensitivity to discriminate the management systems and may be a way to evaluate the quality of a cropped soil.

\section{Conclusion}

The $\mathrm{C}$ and $\mathrm{N}$ labile fractions isolated by the physical fractionation are more efficient to provide information about the changes in soil organic matter quality in a no-till system compared to the labile $\mathrm{C}$ extracted with $\mathrm{KMnO}_{4}$. The diversification of the agricultural system with legume-based annual rotation changes the distribution of $\mathrm{C}$ and $\mathrm{N}$ among the SOM fractions confirming the hypothesis tested.

\section{Acknowledgements}

Authors would like to thank the AGRISUS Foundation (Projects: Agrisus $\mathrm{N}^{\circ} 1414 / 14$ and 1710/15) by the financial support that made possible to achieve this research. The first author gratefully acknowledges support by the Brazilian Government under CAPES-scholarship.

\section{References}

Aziz, I., Ashraf, M., Mahmood, T., \& Islam, K. R. (2011). Crop rotation impact on soil quality. Pakistan Journal of Botany, 43(2), 949-960.

Bayer, C., Mielniczuk, J., Giasson, E., Martin-Neto, L., \& Pavinato, A. (2006). Tillage Effects on particulate and mineral-Associated organic matter in Two Tropical Brazilian soils. Communications in Soil Science and Plant Analyses, 37, 389-400. https://doi.org/10.1080/00103620500446928

Blair, G. J., Lefroy, R. D. B., \& Lisle, L. (1995). Soil carbon fractions based on their degree of oxidation, and development of a carbon management index for agricultural systems. Australian Journal of Agricultural Research, 46(7), 1459-1466. https://doi.org/10.1071/AR9951459

Cambardella, C. A., \& Elliott, E. T. (1992). Particulate Soil Organic-Matter Changes across a Grassland Cultivation Sequence. Soil Science Society of America Journal, 56, 777-783. https://doi.org/10.2136/ sssaj1992.03615995005600030017x

Chen, H. Q., Hou, R. X., Gong, Y. S., Li, H. W., Fan, M. S., \& Kuzyakov, Y. (2009). Effects of 11 years of conservation tillage on soil organic matter fractions in wheat monoculture in Loess Plateau of China. Soil Tillage and Research, 106, 85-94. https://doi.org/10.1016/j.still.2009.09.009

Chen, Y., Li, Y., Awada, T., Han, J., \& Luo, Y. (2012). Carbon sequestration in the total and light fraction soil organic matter along a chronosequence in grazing enclosures in a semiarid degraded sandy site in China. Journal of Arid Land, 4, 411-419. https://doi.org/10.3724/SP.J.1227.2012.00411

Dou, F., Wright, A. L., \& Hons, F. M. (2008). Sensitivity of labile soil organic carbon to tillage in wheat-based cropping systems. Soil Science Society of America, 72(5), 1445-1453. https://doi.org/10.2136/sssaj 2007.0230

Durval, M. E., Galantini, J. A., Iglesias, J. O., Canelo, S., Martinez, J. M., \& Wall, L. (2013). Analysis of organic fractions as indicators of soil quality under natural and cultivated systems. Soil and Tillage Research, 131, 11-19. https://doi.org/10.1016/j.still.2013.03.001

EMBRAPA (Empresa Brasileira de Pesquisa Agropecuária). (2006). Centro Nacional de Pesquisa de Solos. Sistema brasileiro de classificação de solos (p. 306). Rio de Janeiro, Braizl.

FAO. (1988). Soil map of the world. World Soil Resources Report No. 60. FAO-UNESCO-ISRIC, Rome.

Favoretto, C. M., Gonçalves, D., Milori, D. M. B. P., Rosa, J. A., Leite, W. C., Brinatti, A. M., \& Saab, S. C. (2008). Determination of humification degree of organic matter of an Oxisol and of its organic mineral fractions. Quimica Nova, 31, 1994-1996. https://doi.org/10.1590/S0100-40422008000800015

Fornara, D. A., \& Tilman, D. (2008). Plant functional composition influences rates of soil carbon and nitrogen accumulation. Journal of Ecology, 96, 314-322. https://doi.org/10.1111/j.1365-2745.2007.01345.x

Gan, Y., Hamel, C.O, Donovan, J.T., Cutforth, H., Zentner, R.P., Campbell, C.A., Niu, Y. \& Poppy, L. (2015). Diversifying crop rotations with pulses enhances system productivity. Scientific Reports, 5(14625). https://doi.org/10.1038/srep14625 
Gong, W., Yan, X., Wang, J., Hu, T., \& Gong, Y. (2009). Long-term manure and fertilizer effects on soil organic matter fractions and microbes under a wheat-maize cropping system in northern China. Geoderma, 149, 318-324. https://doi.org/10.1016/j.geoderma.2008.12.010

González-Pérez, M., Milori, D. M. B. P., Colnago, L. A., Martin-Neto, L., \& Melo, W. J. (2007). A laser-induced fluorescence spectroscopic study of organic matter in a Brazilian Oxisol under different tillage systems. Geoderma, 138, 20-24. https://doi.org/10.1016/j.geoderma.2006.10.010

Islam, R., Glenney, D. C., \& Lazarovits, G. (2015). No-till strip row farming using yearly maize-soybean rotation increases yield of maize by 75\%. Agronomy for Sustainable Development, 35, 837-846. https://doi.org/10.1007/s13593-015-0289-y

Jamala, G. Y., \& Oke, D. O. (2013). Soil organic carbon fractions as affected by land use in the Sourthern Guinea Savanna ecosystem of Adamawa State, Nigeria. Journal of Soil Science and Environmental Management, 4(6), 116-122. https://doi.org/10.5897/JSSEM2013.0400

Janzen, H. H., Campbell, C. A., Brandt, S. A., Lafond, G. P., \& Townleysmith, L. (1992). Light-fraction organic matter in soils from long-term crop rotations. Soil Science Society of America Journal, 56, 1799-1806. https://doi.org/10.2136/sssaj1992.03615995005600060025x

Junior, P. R. R., Donagemma, G. K., Andrade, F. V., Passos, R. R., Balieiro, F. C., Mendonça, E. S., \& Ruiz, H. A. (2014). Can soil organic carbon pools indicate the degradation levels of Pastures in the Atlantic Forest Biome? Journal of Agricultural Science, 6(1), 84-94. https://doi.org/10.5539/jas.v6n1p84

Karami, A., Homaee, M., Afzalinia, S., Ruhipour, H., \& Basirat, S. (2012). Organic resource management: Impacts on soil aggregate stability and other soil physico-chemical properties. Agriculture, Ecosystems \& Environment, 148, 22-28. https://doi.org/10.1016/j.agee.2011.10.021

Lal, R. (2015). Sequestering carbon and increasing productivity by conservation agriculture. Journal of Soil, Water and Conservation, 70, 55-62. https://doi.org/10.2489/jswc.70.3.55A

Malhi, S. S., \& Lemke, R. (2007). Tillage, crop residue and N fertilizer effects on crop yield, nutrient uptake, soil quality and nitrous oxide gas emissions in a second 4-yr rotation cycle. Soil and Tillage Research, 96, 269-283. https://doi.org/10.1016/j.still.2007.06.011

Manlay, R. J., Feller, C., \& Swift, M. J. (2007). Historical evolution of soil organic matter concepts and their relationships with the fertility and sustainability of cropping systems. Agriculture, Ecosystems and Environment, 119, 217-233. https://doi.org/10.1016/j.agee.2006.07.011

Martins, T., Saab, S. C., Milori, D. M. B. P., Brinatti, A. M., Rosa, J. A., Cassaro, F. A. M., \& Pires, L. F. (2011). Soil organic matter humification under different tillage managements evaluated by Laser Induced Fluorescence (LIF) and C/N ratio. Soil \& Tillage Research, 111, 231-235. https://doi.org/10.1016/ j.still.2010.10.009

Mendonça, E. S., \& Matos, E. S. (2005). Matéria orgânica do solo: Métodos de analyses (p. 107). Viçosa, MG, Universidade Federal de Viçosa.

Milori, D. M. B. P., Martin-Neto, L., Bayer, C., Mielniczuk, J., \& Bagnato, V. S. (2002). Humification degree of soil humic acids determined by fluorescence spectroscopy. Soil Science, 167, 739-749. https://doi.org/ 10.1097/00010694-200211000-00004

Milori, D. M. P. B., Galeti, H. V. A., Martin-Neto, L., Diekow, J., González-Peréz, M., Bayer, C., \& Salton, J. (2006). Organic matter study of whole soil samples using laser-induced fluorescence spectroscopy. Soil Science Society of America Journal, 70, 57-63. https://doi.org/10.2136/sssaj2004.0270

Mujuru, L., Mureva, A., Velthorst, E. L., \& Hoosbeek, M. R. (2013). Land use and management effects on soil organic matter fractions in Rhodic Ferralsols and Haplic Arenosols in Bindura and Shamva districts of Zimbabwe. Geoderma, 209, 262-272. https://doi.org/10.1016/j.geoderma.2013.06.025

Ramnarine, R., Voroney, R. P., Wagner-Riddle, C., \& Dunfield, K. E. (2014). Conventional and No-Tillage Effects on the Distribution of Crop Residues and Light Fraction Organic Matter. Soil Biology \& Biochemistry, Soil Science Society of America Journal, 79, 74-80. https://doi.org/10.2136/sssaj2014. 05.0182

Ryals, R., Kaiser, M., Torn, M. S., Berhe, A. A., \& Silver, W. L. (2014). Impacts of organic matter amendments on carbon and nitrogen dynamics in grassland soils. Soil Biology and Biochemistry, 68, 52-61. https://doi.org/10.1016/j.soilbio.2013.09.011 
Segnini, A., Carvalho, J. L. N., Bolonhezi, D., Milori, D. M. B. P., Silva, W. T. L., Simões, M. L., ... Martin-Neto, L. (2013). Carbon stock and humification index of organic matter affected by sugarcane straw and soil management. Scientia Agricola, 70(5), 321-326. https://doi.org/10.1590/S0103-90162013000 500006

Soon, Y. K., Arshad, M. A., Haq, A., \& Lupwayi, N. (2007). The influence of 12 years of tillage and crop rotation on total and labile organic carbon in a sandy loam soil. Soil and Tillage Research, 95, 38-46. https://doi.org/10.1016/j.still.2006.10.009

Souza, G. P., Figueiredo, C. C. \& Souza, D. M. G. (2016). Relationships between labile soil organic carbon fractions under different soil management systems. Scientia Agricola, 73(6), 535-542. https://doi.org/ 10.1590/0103-9016-2015-0047

Strosser, E. (2010). Methods for determination of labile soil organic matter: An overview. Journal of Agrobiology, 27, 49-60. https://doi.org/10.2478/s10146-009-0008-x

Tan, Z., Lal, R., Owens, L., \& Izaurralde, R. C. (2007). Distribution of light and heavy fractions of soil organic carbon as related to land use and tillage practice. Soil and Tillage Research, 92, 53-59. https://doi.org/ 10.1016/j.still.2006.01.003

Vanhie, M., Deen, W., Lauzon, J. D., \& Hooker, D. C. (2015). Effect of increasing levels of maize (Zea mays L.) residue on no-till soybean (Glycine max Merr.) in northern production regions: A review. Soil and Tillage Research, 150, 201-210. https://doi.org/10.1016/j.still.2015.01.011

Vieira, F. C. B., Bayer, C., Zanatta, J. A., Dieckow, J., Mielniczuk, J., \& He, Z. L. (2007). Carbon management index based on physical fractionation of soil organic matter in an Acrisol under long-term no-till cropping systems. Soil and Tillage Research, 96, 195-2004. https://doi.org/10.1016/j.still.2007.06.007

Wagai, R., Mayer, L. M., \& Kitayama, K. (2009). Nature of the "occluded" low-density fraction in soil organic matter studies: A critical review. Soil Science and Plant Nutrition, 55, 13-25. https://doi.org/10.1111/ j.1747-0765.2008.00356.x

Zhu, L., Hu, N., Zhang, Z., Xu, J., Tao, B., \& Meng, Y. (2015). Short-term responses of soil organic carbon and carbon pool management index to different annual straw return rates in a rice-wheat cropping system. Catena, 135, 283-289. https://doi.org/10.1016/j.catena.2015.08.008

\section{Copyrights}

Copyright for this article is retained by the author (s), with first publication rights granted to the journal.

This is an open-access article distributed under the terms and conditions of the Creative Commons Attribution license (http://creativecommons.org/licenses/by/4.0/). 